\title{
Spatiotemporal proliferation of human stromal cells adjusts to nutrient availability and leads to stanniocalcin-1 expression in vitro and in vivo
}

Citation for published version (APA):

Higuera, G. A., Fernandes, H., Spitters, T. W. G. M., van de Peppel, J., Aufferman, N., Truckenmueller, R., Escalante, M., Stoop, R., van Leeuwen, J. P., de Boer, J., Subramaniam, V., Karperien, M., van Blitterswijk, C., van Boxtel, A., \& Moroni, L. (2015). Spatiotemporal proliferation of human stromal cells adjusts to nutrient availability and leads to stanniocalcin-1 expression in vitro and in vivo. Biomaterials, 61, 190-202. https://doi.org/10.1016/j.biomaterials.2015.05.017

Document status and date:

Published: 01/08/2015

DOI:

10.1016/j.biomaterials.2015.05.017

Document Version:

Publisher's PDF, also known as Version of record

Document license:

Taverne

Please check the document version of this publication:

- A submitted manuscript is the version of the article upon submission and before peer-review. There can be important differences between the submitted version and the official published version of record.

People interested in the research are advised to contact the author for the final version of the publication, or visit the DOI to the publisher's website.

- The final author version and the galley proof are versions of the publication after peer review.

- The final published version features the final layout of the paper including the volume, issue and page numbers.

Link to publication

\footnotetext{
General rights rights.

- You may freely distribute the URL identifying the publication in the public portal. please follow below link for the End User Agreement:

www.umlib.nl/taverne-license

Take down policy

If you believe that this document breaches copyright please contact us at:

repository@maastrichtuniversity.nl

providing details and we will investigate your claim.
}

Copyright and moral rights for the publications made accessible in the public portal are retained by the authors and/or other copyright owners and it is a condition of accessing publications that users recognise and abide by the legal requirements associated with these

- Users may download and print one copy of any publication from the public portal for the purpose of private study or research.

- You may not further distribute the material or use it for any profit-making activity or commercial gain

If the publication is distributed under the terms of Article 25fa of the Dutch Copyright Act, indicated by the "Taverne" license above, 


\title{
Spatiotemporal proliferation of human stromal cells adjusts to nutrient availability and leads to stanniocalcin-1 expression in vitro and in vivo
}

\author{
Gustavo A. Higuera ${ }^{\mathrm{a},{ }^{*}, \text { Hugo Fernandes }}{ }^{\text {a }}$, Tim W.G.M. Spitters ${ }^{\text {a }}$, Jeroen van de Peppel ${ }^{\mathrm{b}}$, \\ Nils Aufferman ${ }^{a}$, Roman Truckenmueller a, Maryana Escalante c , Reinout Stoop ${ }^{\mathrm{d}}$, \\ Johannes P. van Leeuwen ${ }^{b}$, Jan de Boer ${ }^{a}$, Vinod Subramaniam ${ }^{\text {c }}$, Marcel Karperien ${ }^{\mathrm{a}}$, \\ Clemens van Blitterswijk ${ }^{a}$, Anton van Boxtel ${ }^{\mathrm{e}}$, Lorenzo Moroni ${ }^{\mathrm{a}}$ \\ a Department of Tissue Regeneration, MIRA - Institute for Biomedical Technology, University of Twente, Drienerlolaan 5, 7522 NB Enschede, \\ The Netherlands \\ ${ }^{\mathrm{b}}$ Erasmus Medical Center, Internal Medicine, Wytemaweg 80, 3015 CN Rotterdam, The Netherlands \\ ${ }^{c}$ Biophysical Engineering Group, Mesa ${ }^{+}$Institute for Nanotechnology, University of Twente, Drienerlolaan 5, 7522 NB Enschede, The Netherlands \\ d TNO, Metabolic Health Research, Zernikedreef 9, 2333 CK Leiden, The Netherlands \\ e Systems and Control Group, Wageningen University, PO Box 17, 6700 AA Wageningen, The Netherlands
}

\section{A R T I C L E I N F O}

\section{Article history:}

Received 3 February 2015

Received in revised form

5 May 2015

Accepted 14 May 2015

Available online 15 May 2015

\section{Keywords:}

Angiogenesis

ECM (extracellular matrix)

Mesenchymal stromal cells

Microarchitecture

Molecular gradients

\begin{abstract}
A B S T R A C T
Cells and tissues are intrinsically adapted to molecular gradients and use them to maintain or change their activity. The effect of such gradients is particularly important for cell populations that have an intrinsic capacity to differentiate into multiple cell lineages, such as bone marrow derived mesenchymal stromal cells (MSCs). Our results showed that nutrient gradients prompt the spatiotemporal organization of MSCs in 3D culture. Cells adapted to their 3D environment without significant cell death or cell differentiation. Kinetics data and whole-genome gene expression analysis suggest that a low proliferation activity phenotype predominates in stromal cells cultured in 3D, likely due to increasing nutrient limitation. These differences implied that despite similar surface areas available for cell attachment, higher cell concentrations in 3D reduced MSCs proliferation, while activating hypoxia related-pathways. To further understand the in vivo effects of both proliferation and cell concentrations, we increased cell concentrations in small $(1.8 \mu \mathrm{l})$ implantable wells. We found that MSCs accumulation and conditioning by nutrient competition in small volumes leads to an ideal threshold of cell-concentration for the induction of blood vessel formation, possibly signaled by the hypoxia-related stanniocalcin-1 gene.
\end{abstract}

() 2015 Elsevier Ltd. All rights reserved.

\section{Introduction}

Energy in the form of nutrients influences stromal cell proliferation. But, how do nutrients influence stromal cell proliferation in $3 \mathrm{D}$ ? In the context of embryonic development, stromal cell proliferation is well-studied and known to be regulated by both physical and biochemical signals [1,2]. In adult tissues, cell division underlies tissue maintenance, such as in haematopoiesis and bone remodeling, which are the biological foundations of musculoskeletal tissue regeneration [3]. Two-dimensional (2D) cell culture

\footnotetext{
* Corresponding author.

E-mail address: g.higuerasierra@erasmusmc.nl (G.A. Higuera).
}

systems have been used to unravel physical stimulants and molecular mechanisms [2, 4, 5] for stromal cell activity, such as the effect of surface topography [4] and geometry [5]. Increasingly, three-dimensional (3D) systems reveal new stimulants of stromal cell activity, such as pressure [6, 7] and molecular gradients of oxygen, glucose and growth factors [8-13]. Molecular gradients occur when the distribution of a molecule is not spatially homogeneous as determined by diffusion and/or convection principles [14]. As suggested for oxygen [15, 16] and trophic factors [17], the response of stromal cells depends on concentrations for a particular molecule. In this regard, soluble molecules and their biophysical dynamics present an important challenge, because molecular gradients over short (nanometers) and large (micrometers and millimeters) distances define the milieu of developing and adult tissues 
[18]. In developing tissues, concentration gradients have important roles, such as in the migration of distant cells [19]. This occurs via a chemotaxis-driven [18] process involving morphogens [20] that induce cell migration. Concentration gradients have been mimicked in vitro to recreate the spatial and temporal characteristics [2] of adult tissues. In this manner, the homeostatic roles of molecular gradients have been studied for osteochondral [11, 13, 21] and cardiac [8] tissues. Here, we explored the spatiotemporal proliferation of human mesenchymal stromal cells (MSCs) in 3D systems, that is scaffolds and wells [22], considering predictable molecular gradients developed during culture. Scaffolds were used to control the 3D location of cells whereas wells allowed seeding of cell concentrations $>3 \times 10^{6}$ cells $/ \mathrm{ml}$ [22], which cannot be frequently achieved in scaffolds. In particular, we focused on studying how MSCs activity and organization occur in 3D in comparison to 2D culture systems. A more in-depth understanding of the physical and molecular events behind MSCs activity in 3D may ultimately result in better strategies for cell therapy and the design of implants for regenerative medicine applications.

\section{Materials and methods}

For disc and scaffold fabrication, poly(ethylene oxide terephthalate)-poly(butylene terephthalate) (PEOT/PBT, PolyVation, Groningen, The Netherlands) of the 300PEOT55PBT45 composition was used. According to its nomenclature aPEOTbPBTc, (a) the molecular weight of starting poly(ethylene glycol) PEG blocks was $300 \mathrm{~g} / \mathrm{mol}$ and ( $\mathrm{b}$ and c) the weight percentage ratio PEOT/PBT was 55/45 [28].

\subsection{Fabrication of the two-dimensional discs}

Granules of 300PEOT55PBT45 were placed inside circular features through holes of $2.2 \mathrm{~cm}$ in diameter in a stainless steel mold were placed in between two silicon wafers that served as support and defined the molded surface for the hot embossing process. Cleaning of the support and the hot embossing process was performed as described before [24].

\subsection{Fabrication of the three-dimensional scaffolds}

3D scaffolds were fabricated with a Bioplotter device (Envisiontec GmbH, Germany), which is an XYZ plotter previously described before [37]. In this study, the scaffold fabrication process is similar to a previous study [28]. Briefly, cylindrical block models were CAD-designed with Rhinoceros software (Delft, The Netherlands) and loaded on the Bioplotter CAM software (PrimCAM, Einsiedeln, Switzerland). In addition, polymer granules were loaded in a stainless steel syringe and heated at $200{ }^{\circ} \mathrm{C}$ in a thermal cartridge unit mounted on the mobile X-arm of the apparatus. A nitrogen pressure of 4 Bar was applied to the syringe when the polymer melted. Nitrogen was used in order to minimize the copolymer oxidation. The combination of software and physical set-up resulted in the extrusion of melted 300PEOT55PBT45 in the form of fibers deposited layer-by-layer onto a stage.

The fiber diameter was controlled with stainless steel Luer Lock hypodermic needles (Unimed, Lausanne, Switzerland) with internal diameter (ID) of $250 \mu \mathrm{m}$. This needle diameter was chosen because experimentally it showed a good compromise in terms of feasible scaffold porosities and fabrication time as previous studies have shown [38]. The fiber spacing, layer thickness, and fiber deposition speed were inputs in the CAM software. Three cylindrical block models were printed: (A) $9.4 \mathrm{~mm}$ diameter $\times 1 \mathrm{~mm}$ height and (B) $8 \mathrm{~mm}$ diameter $\times 3 \mathrm{~mm}$ height. Design A was used in kinetics studies and to make pore architectures with a $45^{\circ}$ angle of successive layers. Design B was used in bioreactor experiments. The fiber spacing was $0.65 \mathrm{~mm}$ and $1 \mathrm{~mm}$ for designs $A$ and $B$, respectively. The layer thickness was $0.15 \mathrm{~mm}$ and the fiber deposition speed was $320 \mathrm{~mm} / \mathrm{min}$ for all designs. The deposition speed was increased in steps of 5\% every 20 min to adjust for the change in polymer viscosity due to degradation. Scaffold architecture included deposition of fibers in each layer at $90^{\circ}$ angles of the successive layers for static and perfusion bioreactor cultures.

\subsection{Isolation, culture and cryopreservation of stromal cells}

We isolated, cultured, and cryopreserved human mesenchymal stem cells (stromal cells) as described by Both et al. [41]. We obtained stromal cells from donors who were undergoing total hip replacement surgery and gave informed consent for bone marrow biopsy, approved by the local medical ethical committee. Mononucleated cells were counted in the aspirate and plated at a density of 500,000 cells $/ \mathrm{cm}^{2}$ in T-flasks (Nunc, Thermo Fischer Scientific, Roskilde, Denmark).

After addition of $\alpha$-minimal essential medium ( $\alpha \mathrm{MEM}$ ) proliferation medium, cells were cultured for four to five days. The aMEM proliferation medium contained minimal essential medium (GIBCO, Carlsbad, CA), 10\% fetal bovine serum of a selected batch (FBS; Biowhittaker, lot:8SB0002; from Lonza, Verviers, Belgium), $0.2 \mathrm{mM}$ l-ascorbic-acid-2-phosphate (Sigma, St. Louis, MO), penicillin G (100 Units/ml, Invitrogen, Carlsbad, CA); streptomycin (100 $\mu \mathrm{g} / \mathrm{ml}$, Invitrogen), $2 \mathrm{mM}$ L-glutamine (Sigma), and $1 \mathrm{ng} / \mathrm{ml}$ basic fibroblast growth factor (Instruchemie, Delfzijl, The Netherlands). Cells were cultured in incubator at $37{ }^{\circ} \mathrm{C}$ in a humidified atmosphere of $5 \%$ carbon dioxide.

After the four to five day culture period, non-adherent cells and aMEM proliferation medium were discarded. Adherent cells were thoroughly washed twice with PBS phosphate-buffered-saline (PBS, Sigma) and $\alpha$ MEM proliferation medium was refreshed. We proliferated adherent cells for two passages and cryopreserved them. The passage number was defined by every harvest with $0.25 \%$ trypsin/EDTA (GIBCO).

\subsection{Stromal cells expansion prior to scaffold seeding}

Cryopreserved cells were thawed and stromal cells - passage 2 - were recounted and plated at 1000 cells $/ \mathrm{cm}^{2}$ in $300 \mathrm{~cm}^{2}$ T-flasks (T-300 flasks) in aMEM proliferation media. Stromal cells were cultured for one week (Approx. 25 population doublings depending on the donor) with one refreshment of $\alpha$ MEM proliferation media.

\subsection{Scaffold sterilization and conditioning for stromal cells culture}

2D and 3D scaffolds were sterilized with 70\% Ethanol solution for $15 \mathrm{~min}$. After, scaffolds were washed and incubated at room temperature for two hours with sterile PBS. We repeated this washing step three times. Then, 2D and 3D scaffolds were incubated in $\alpha$ MEM proliferation media overnight at standard culture conditions before seeding.

\subsection{Dynamic seeding of $2 D$ and $3 D$ scaffolds}

Once stromal cells were semi confluent during expansion, stromal cells were harvested with $0.25 \%$ trypsin/EDTA. From the cell suspension, $200 \mu \mathrm{l}$ were diluted in $10 \mathrm{ml}$ of Isoton II diluent (Beckman Coulter, Fullerton, CA) and three drops of Zap-OGlobin II lytic reagent (Beckman Coulter) were added. The solutions were incubated for $30 \mathrm{~min}$ to maximize the effect of the lytic reagent, and subsequently, the nuclei of cells were counted in a particle count and size analyzer ( $\mathrm{Z2}$, Beckman Coulter). The size range of counted 
nuclei was set between 6 and $10.5 \mu \mathrm{m}$ according to the 95\% confidence interval of stromal cells nuclei size. After cell counting, a volume from the cell suspension equivalent to $2 \times 10^{5}$ stromal cells - passage 3 - were seeded per scaffold and adjusted to $1 \mathrm{ml} /$ well as seeding volume in wells of non-tissue-culture treated plates (10 $\mathrm{cm}^{2}$ per well, Nunc). Bioreactor culture and its static control required seeding $1.5 \times 10^{6}$ stromal cells with seeding volume adjusted to $2 \mathrm{ml} /$ well because the bioreactor scaffolds were larger than scaffolds dimensions (see above) used only in static experiments.

To induce homogeneous seeding, the six-well plates were placed on a rocking bed (Heidolph Instruments, Schwabach, Germany) at 30 (RPM) for four hours in standard culture conditions. After seeding, well plates were removed from the rocking bed and placed in an incubator or in the perfusion bioreactor.

\subsection{Stromal cells static culture on $2 D$ and $3 D$ scaffolds}

Every well on the six well plate contained $4 \mathrm{ml}$ of $\alpha \mathrm{MEM}$ proliferation medium, which was refreshed every week. After dynamic seeding and thereafter, every other day, three 2D discs and three 3D scaffolds were removed from culture to obtain viable cell numbers. 2D discs and 3D scaffolds were washed with PBS before any further treatment was performed. In addition, a medium sample was drawn every other day to obtain dead cell numbers and a metabolic profile. RNA was isolated using Trizol (Invitrogen) according to the manufacturer and used for whole-genome analysis.

\subsection{Whole genome expression analysis}

Briefly, 750 ng of cRNA was hybridized on the array overnight after which the array was washed and blocked. Then, by addition of streptavidin Cy-3 a fluorescent signal was developed. Arrays were scanned on an Illuminai Scan reader and raw intensity values were background corrected in GenomeStudio (Illumina). Further data processing and statistical testing were performed with $\mathrm{R}$ and Bioconductor statistical software (http://www.bioconductor.org/), using package lumi. Raw intensity values were transformed using variance stabilization and a quantile normalization was performed. A linear modeling approach with empirical Bayesian methods, as implemented in Limma package [23], was applied for differential expression analysis of the resulting probe-level expression values. A gene list containing only differentially expressed genes was generated.

\subsection{Metabolic profile and volume}

Medium samples were obtained every other day for every donor from independent wells $(\mathrm{n}=3$ ). Glucose, lactate, and ammonia were in the Vitros DT60 II chemistry system (Ortho-Clinical Diagnostics, Tilburg, The Netherlands), which relies on oxidation of glucose, lactate and ammonia that leads to production of a dye whose intensity is assessed via light reflection.

\subsection{Spontaneous lactate dehydrogenase degradation}

All spontaneous degradation experiments included medium incubated at standard culture conditions, where LDH was measured with Cytotox-one Homogeneous Membrane Integrity Assay (Promega Corporation, Madison, WI). Lactate-dehydrogenase (LDH) signal for dead cell numbers degraded linearly in time at a rate of $1.3 \times 10^{2}\left(\mathrm{R}^{2}=0.88\right)$. $\mathrm{LDH}$ signal/h was measured from three replicates per data point. $\mathrm{LDH}$ signals were normalized for every donor to LDH spontaneous degradation before dead cell numbers were calculated.

\subsection{Sample preparation for biochemical analysis}

PEOT/PBT 2D discs and 3D scaffolds were washed with PBS and frozen overnight at $-80^{\circ} \mathrm{C}$. For DNA, glycosaminoglycans (GAG), and total collagen quantification, all samples were digested for $16 \mathrm{~h}$ at $56{ }^{\circ} \mathrm{C}$ with $1 \mathrm{mg} / \mathrm{ml}$ proteinase $\mathrm{K}$ (Sigma-Aldrich) in Tris/ EDTA buffer ( $\mathrm{pH}$ 7.6). This solution also contained $18.5 \mu \mathrm{g} / \mathrm{ml}$ iodoacetamide and $\mu \mathrm{g} / \mathrm{ml}$ pepstatin A (Sigma-Aldrich).

\subsection{Viable and dead stromal cells}

Viable cell numbers were obtained with Cyquant DNA assay (Invitrogen). Cell numbers were calibrated for every stromal cells donor by measuring the DNA signal $(n=3)$ of six cell numbers from $1 \times 10^{4}$ to $3 \times 10^{5}$ cells. Cell numbers were plotted against DNA amount and analyzed by linear regression to obtain DNA signal/cell number ratio (donor 1: $4.9 \times 10^{-1}, \mathrm{R}^{2}=0.96$; donor 2: $4.2 \times 10^{-1}$, $\mathrm{R}^{2}=0.91$; and donor $\left.3: 2.6 \times 10^{-1}, \mathrm{R}^{2}=0.94\right)$. DNA from three scaffolds per donor was obtained to obtain each cell number data point. Cell numbers for every donor were obtained by dividing the signal in time by their respective DNA signal/cell number ratio.

Cell death was quantified with medium analysis of the LDH signal with the Cytotox-one Homogeneous Membrane Integrity Assay (Promega Corporation, Madison, WI), which allowed cell death quantification - through LDH - from medium samples collected every other day for every donor from independent wells $(n=3)$. Cell numbers were plotted against LDH signal $(n=3)$ for each of five cell numbers from $2 \times 10^{3}$ to $2.5 \times 10^{5}$ cells. The slope estimated from linear regression corresponded to the LDH signal/ cell number ratio (donor 1: $1.51 \times 10^{-1}, \mathrm{R}^{2}=0.92$; donor 2: $6.99 \times 10^{-1}, \mathrm{R}^{2}=0.94$; and donor $3: 1.15, \mathrm{R}^{2}=0.92$ ), showing that the method was sufficiently sensitive to estimate dead cell numbers. From three runs per donor, i.e. three wells measured per measurement day, four medium samples per run $(n=12)$ were obtained and its LDH signal measured in time. Dead cell numbers for every donor were obtained by dividing the signal in time by their respective $\mathrm{LDH}$ signal/cell ratio.

\subsection{Nude mice implantations}

After consent from the medical ethical committee for animal studies (DEC-GDL Utrecht, The Netherlands), scaffolds and well systems were implanted in posterior-lateral side of the back of 30 six-week old nude mice (Hdcpb:NMRI-nu Harlan, The Netherlands) after anesthetization with $0.02 \mathrm{ml}$ of a 3.5:3:1 mixture of ketamine $(100 \mu \mathrm{g} / \mathrm{ml})$ : Xylazine $(20 \mu \mathrm{g} / \mathrm{ml})$ : atropine $(0.5 \mu \mathrm{g} / \mathrm{ml})$. After 2 weeks $(n=10)$ and 4 weeks $(n=10)$, mice were euthanized via $\mathrm{CO}_{2}$ asphyxiation for excision of wells and scaffolds. Four scaffolds per mouse were implanted in the posterior-lateral side of the back in a total of 10 nude mice and sutured. Scaffolds were seeded with stromal cells as described above and implanted on day 8 of in vitro culture.

\subsection{Well systems}

Nine-well systems (Vers3D ${ }^{\mathrm{TM}}$, Screvo B.V., The Netherlands) of $1.8 \mu$ l were seeded with 3,7 and $14 \times 10^{9}$ stromal cells/L in triplicates for each concentration for a total of 9 conditions implanted in 20 nude mice as part of 36 conditions implanted before [24]. Briefly, well systems made from 300PEOT55PBT45 were implanted and sutured as described above for scaffolds. Stromal cells concentrations were randomized by dispensing conditions in different wells of a well system and excised on weeks $2(n=10)$ and $4(n=10)$. 


\subsection{Immunohistochemistry and histological analysis}

Scaffold samples were fixed for $30 \mathrm{~min}$ in $1.5 \%$ glutaraldehyde (Merck) in $0.14 \mathrm{M}$ cacodylate buffer ( $\mathrm{pH}=7.2-7.4$ ). Samples were then dehydrated in sequential ethanol series, which were embedded in glycol-methacrylate (Merck) for scaffolds and embedded in paraffin (Leica Microsystems, The Netherlands) for well systems. All samples were cut using a microtome into $5 \mu \mathrm{m}$ sections. For imaging scaffolds at low resolution after fixation, scaffolds were stained with $1 \%$ methylene blue (Sigma-Aldrich) to visualize cell membranes on 3D scaffolds through light microscopy. Samples were incubated for $30 \mathrm{~min}$ (RT) in PBS with $\mathrm{H}_{2} \mathrm{O}_{2}$ (30\%) and Na-Azide $(10 \%)$ to remove blood outside of blood vessels in sections. Overnight incubation of well sections with CD31 (1:200, rabbit polyclonal, Abcam) and STC1 (1:200, Chicken polyclonal, Abcam) was performed. Fluorescent images for STC1 (1:200, Cy5) and CD31 (1:200, AF488) were acquired with an LSM700 confocal microscope (Zeiss). For quantitative analysis, at least three images per condition per animal were pooled for 5 animals on week 2 ( $n \geq 15$ images/condition) and 5 animals on week 4 ( $n \geq 15$ images/ condition) were analyzed with image software (open source), where each image was processed as follows. Sections processed without primary antibody showed insignificant autofluorescence for the Cy5 fluorophore and significant autofluorescence for the AF488 fluorophore. Because of the high autofluorescence of the AF488 fluorophore as measured by the mean intensity on histograms ( $12 \pm 8.5, \mathrm{n}=10$ sections), CD31 quantification required segmentation through a Gaussian blur filter (sigma $=2$ ) and manual thresholding (level 66-255). After, the function "analyze particles" (size: 150-infinity, circularity: 0.1-1) was used for obtaining vessel measurements. For STC1 quantification, each image was thresholded with the "Otsu dark" function followed by analyze particles (size: 0-infinity, circularity: 0-1) for obtaining the total area of STC1 fluorescent pixels in a frame. Click-iT ${ }^{\mathbb{B}}$ EdUAlexa Fluor $^{\circledR} 488$ Imaging Kit (Invitrogen) was used to image the DNA synthesis by proliferating stromal cells in 3D scaffolds. 3D scaffolds with stromal cells were incubated in a 1:1 solution of EDU in proliferation medium at $37^{\circ} \mathrm{C}$ for $18 \mathrm{~h}$. Then, samples were fixed in $1 \%$ formalin (Sigma-Aldrich) for $30 \mathrm{~min}$, embedded in Tissue-Tek OCT (Qiagen, The Netherlands), and placed at $-80 \mathrm{C}^{\circ}$ overnight. Five $\mu \mathrm{m}$ sections were cut with a cryomicrotome. Subsequently, sections were permeabilized and washed with the secondary antibody (horseradish perxidase conjugated goat-anti-human immunoglobulin antibody, Dako, Denmark). Sections were counterstained with DAPI (Invitrogen). We used fluorescent microscopy to visualize EDU (DNA) and DAPI (cell nuclei) signals. Representative images were then fused together in Photomatrix Pro 3.2.7 software (HDRsoft, France).

\subsection{Statistical analysis}

All data points for viable and dead cell numbers, GAGs, collagen, glucose, lactate, and ammonia are based on 6 replicates/donor, i.e. six scaffolds used for cell number quantification per data point or six medium samples taken from stromal cells cultures per data point. Error bars in graphs with experimental data represent the standard deviation of measurements. Statistical analysis of means for the parameters mentioned above was performed with the kinetic model as described before [24]. Briefly, culture of stromal cells in 2D and 3D were considered batch systems, where cells grow on their metabolites according to previously reported mammalian cell cultures (44-47). Cell numbers, glucose, lactate and GAG measurements were analyzed with a set of ordinary differential equations (ODEs) which were solved as described before [22]. The initial values for solving the differential equation were set to the seeding density and the experimentally determined composition (glucose, lactate and ammonia) in fresh $\alpha$ MEM proliferation medium from three medium samples. Metabolic rates for the three donors were obtained by nonlinear least squares regression, which minimizes the sum of the quadratic error over an experiment (Matlab function nlinfit). Next, the 95\% confidence intervals for the parameters were calculated (Matlab function nlparci). The data for three sections per condition per animal $(n=7)$ were analyzed for both CD31 and STC1 quantification. The mean and standard error of these measurements were analyzed in Matlab with one-way Anova (anova1 function followed by Tukey's (function: Multcompare) and statistical significance set at $95 \%$.

\subsection{Computational fluid dynamics (CFD)}

CFD models of the laminar flow (mmglf) combined with transport of diluted species (chcd) for culture conditions were set-up in Comsol Multiphysics version 4.1 software (Comsol, The Netherlands). The equation for laminar flow that was solved for incompressible fluid dynamics is defined by Eq. (1) and parameters defined (see Table 2 in Ref. [25]):

$\rho \frac{\partial \boldsymbol{u}}{\partial t}+\rho\left(\boldsymbol{u}^{*} \nabla\right)=\nabla^{*}\left[-\rho I+\mu\left(\nabla \boldsymbol{u}+(\nabla \boldsymbol{u})^{T}\right)\right]+F$
$\rho \nabla^{*} \boldsymbol{u}=0$

where $\rho$ is the fluid density $\left(\mathrm{kg} \mathrm{m}^{-3}\right), \boldsymbol{u}$ is the velocity field $\left(\mathrm{m} \mathrm{s}^{-1}\right), t$ is the time (s), $\mu$ is the dynamic viscosity of the fluid $\left(\mathrm{kg} \mathrm{m}^{-1} \mathrm{~s}^{-1}\right), \nabla$ is the del operator, and $F$ represents other forces (gravity or centrifugal force), which in this case equal to 0 .

The equation for transport of diluted species are represented by Eq. (2) with parameters from (See Table 2 in Ref. [25]):

$\frac{\partial c_{j}}{\partial t}+\nabla^{*}\left(-D_{j} \nabla c_{j}\right)+\boldsymbol{u}^{*} \nabla c_{j}=R_{j}$

$N_{j}=-D_{j} \nabla c_{j}+\boldsymbol{u}^{*} c_{j}$

where $\mathrm{c}$ is the glucose concentration $\left(\mathrm{kg} \mathrm{m}^{-3}\right)$, $\mathrm{D}$ is the diffusion constant of glucose and $\mathrm{R}$ is the consumption rate of glucose by stromal cells.

Glucose distribution was modeled in a $0.65 \times 0.65 \mathrm{~mm}$ channel, which represented the top view of a vertical channels in the scaffold. Walls in different conditions were considered rigid and impermeable and no-slip boundary conditions were applied to these walls. The glucose diffusion constant $(D)$ was $9 \times 10^{-10} \mathrm{~m}^{2} / \mathrm{s}$ (48) and the initial concentration of glucose $(C O=4.5 \mathrm{mmol} / \mathrm{l})$ was obtained from the average bulk concentration of glucose on day 8 for 3D cultures (Fig. 3). Cells were assumed to be positioned on the walls and the glucose flux towards the cells was at a rate of $-1.25 \times 10^{-9} \mathrm{~mol} / \mathrm{m}^{2} / \mathrm{s}$. This was calculated from empirically obtained glucose consumption rates for 3D culture. Glucose distributions in the channel were modeled from day 8 till day 9 .

\subsection{8. $2 D$ and $3 D$ design}

The same area in 2D discs and 3D scaffolds was obtained on the assumption that the ratio of the volume of a porous cylinder $\mathrm{B}\left(V_{B}\right)$ to the volume of a porous cylinder $C\left(V_{C}\right)$ equals the ratio of the cross sectional area of a porous cylinder $\mathrm{B}\left(A_{B}\right)$ to the cross sectional area of a porous cylinder $\mathrm{C}\left(A_{C}\right)$, as depicted in Eq. (3).

$\frac{V_{B}}{V_{C}}=\frac{A_{B}}{A_{C}}$

From Eq. (3), we obtained Eq. (4), 
a

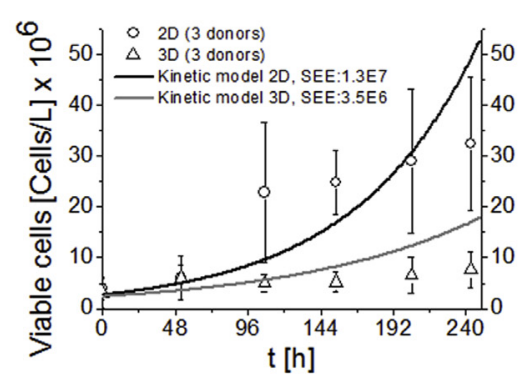

$\mathrm{b}$

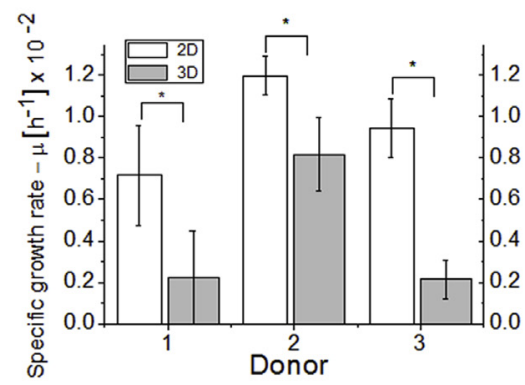

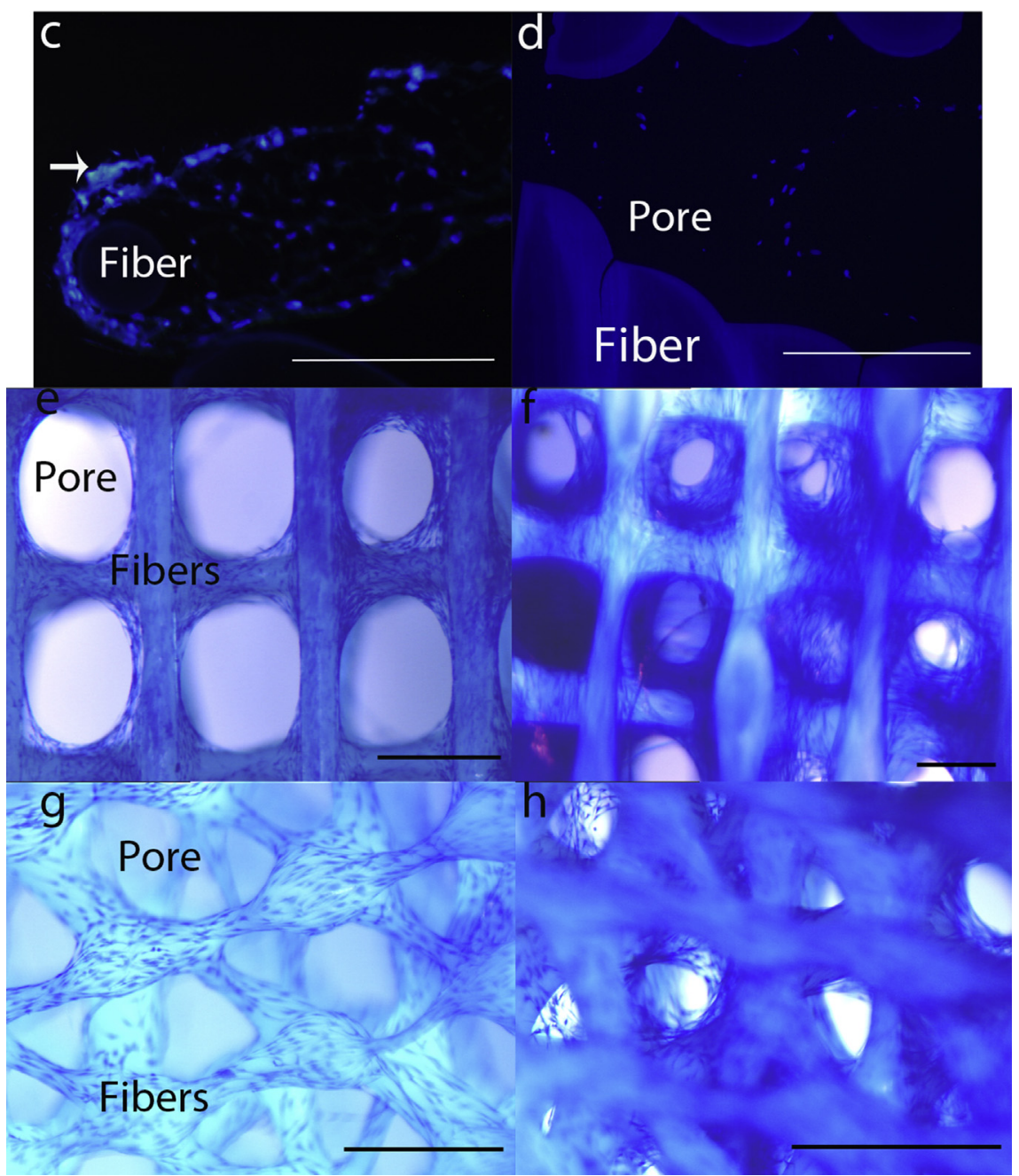

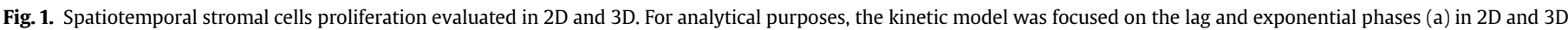

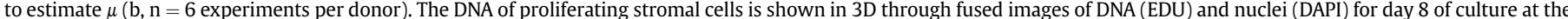

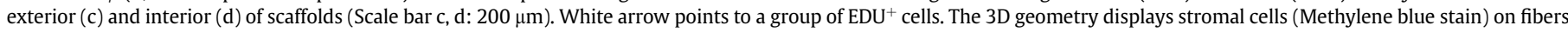

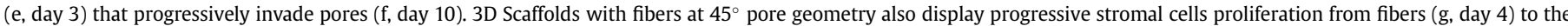

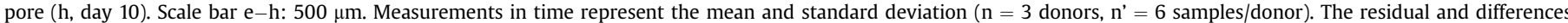

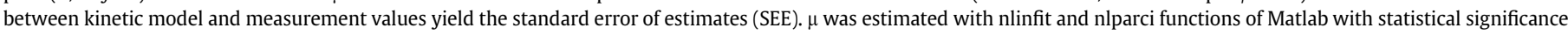
set at $\mathrm{p} \leq 0.05$. (For interpretation of the references to color in this figure legend, the reader is referred to the web version of this article.)

$r_{c}=r_{B} \cdot \sqrt{\frac{A_{C}}{A_{B}}}$

where $A_{B}\left(2.75 \mathrm{~cm}^{2}\right)$ is the area calculated with $\mu \mathrm{CT}$ of a porous scaffold of $0.4 \mathrm{~cm}$ radius $\left(r_{B}\right) . A_{C}$ is the target area $\left(3.79 \mathrm{~cm}^{2}\right)$ and $r_{C}$ its corresponding unknown radius. With Eq. (4), we estimated a radius equal to $0.47 \mathrm{~cm}$ in the 3D scaffold. Fig. 1 in Ref. [25] shows the 3D scaffold radius to area relation. On this figure, $\mu \mathrm{CT}$ experimentally confirmed that an $r_{C}$ of $0.47 \mathrm{~cm}$ produced an area equal to $3.8 \pm 0.47 \mathrm{~cm}^{2}$. All other areas can be deduced in the same manner. $\mu \mathrm{CT}$ measurements showed that the surface area of $2 \mathrm{D}$ discs was equal to $3.87 \pm 0.05 \mathrm{~cm}^{2}$, thereby making 2D discs and 3D scaffold surface areas comparable. 
a

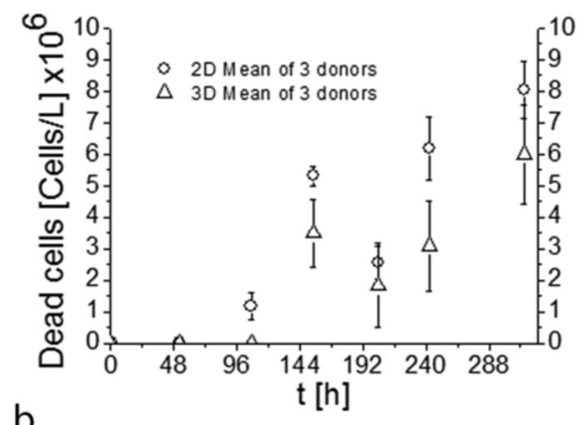

b

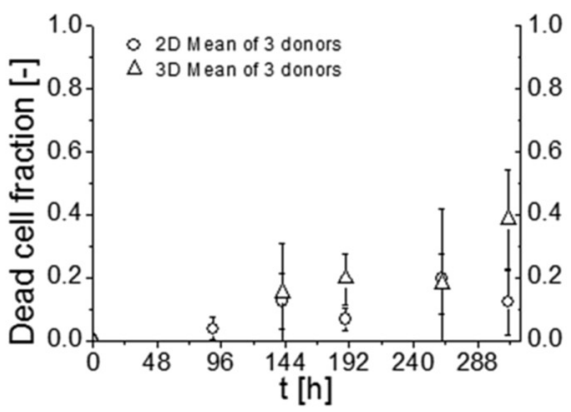

C

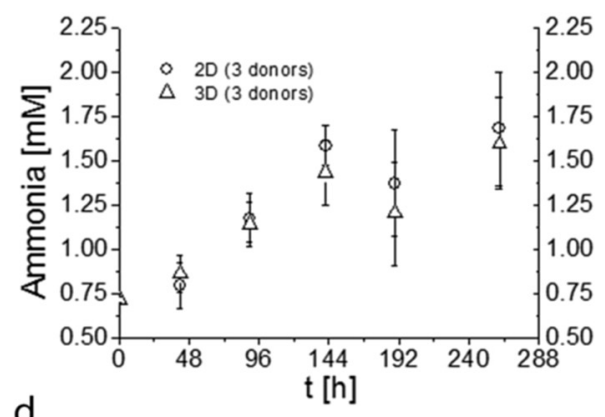

d
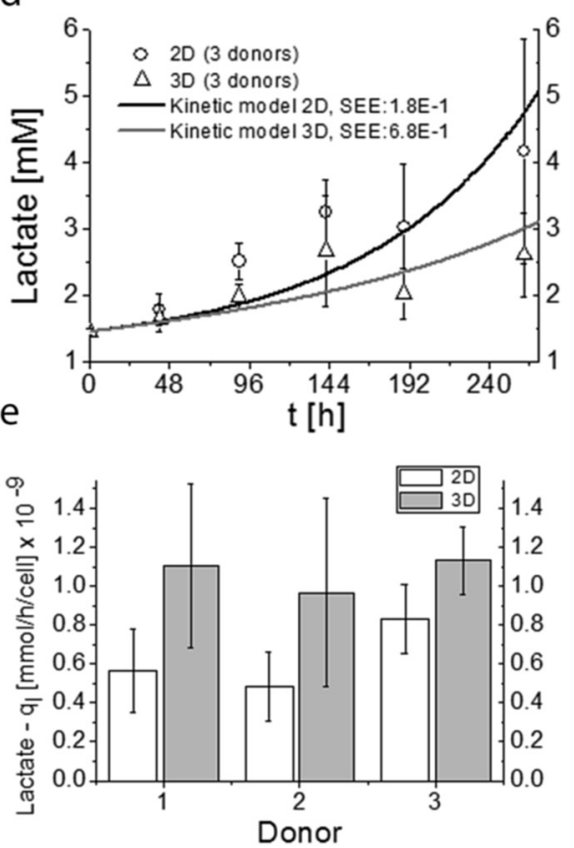

Fig. 2. Dead cell concentration and waste accumulation in 2D and 3D. Dead cell numbers increase in time (a), but remain comparable in 2D and 3D according to the dead cell fraction (dead/dead + viable) for the first 10 days of culture (b). Ammonia

\section{Results}

\subsection{What is the difference between cell proliferation in $2 D$ vs. $3 D$ ?}

To explore the proliferation potential of MSCs, we created 2D (see Fig. 1a in Ref. [25]) and 3D (see Fig. 1b in Ref. [25]) cell culture platforms of poly(ethylene oxide terephthalate)/poly(butylene terephthalate) (PEOT/PBT) biocompatible polymers with comparable attachment-surface areas (see Fig. 1c in Ref. [25]), which was accomplished with $\mu$ CT scans of 3D scaffolds (see Fig. 1b in Ref. [25]). From these scans, it was determined that the attachment area was proportional to the radius of the 3D scaffold (see Fig. 1c in Ref. [25]) according to Eqs. (3) and (4).2D films were designed to match the 3D scaffold area while maintaining similar processing parameters as 3D scaffolds. This allowed us to seed and culture MSCs at comparable seeding densities for each cell donor in both proliferation systems (see Table 1 in Ref. [25]), where donor dependency was observed for the seeding density and efficiency. Proliferation kinetics were determined by quantifying cell accumulation over time (Fig. 1a) and systematic analysis of the data with a deterministic proliferation kinetics model [24] (Fig. 1a) for the lag and exponential phases in 2D. According to the standard error of estimates (SEE), the fit was more accurate for 3D than 2D cultures. Furthermore, it was estimated that specific growth rates, as reflected by cell numbers ( $\mathrm{n}=6$ replicates per donor), were significantly higher in 2D than in 3D (Fig. 1b). Proliferation was observed in the scaffolds periphery as evidenced by EDU staining on day 8 of cell culture (arrow Fig. 1c), whereas no EDU positive cells were observed in the center of the scaffolds at the same time point (Fig 1d, day 8). In addition, MSCs proliferated from the scaffold's fibers (Fig. 1e) towards the center of the scaffold's pore (Fig. 1f). In short, these observations showed that proliferation of MSCs was not evenly distributed across the 3D volume. To exclude that this was a geometry-driven effect, MSCs were seeded on fibers with a $45^{\circ}$ angle pore architecture in 3D scaffolds (Fig. 1g). In these scaffolds, a similar pattern of proliferation from the fiber towards the center of the pore was observed (Fig. 1h), showing that neither the fiber position nor the pore shape affect the direction of cell proliferation.

Since the number of viable cells could be underestimated in the event of cell death, dead cells were quantified (Fig. 2a) in time through analysis of lactate dehydrogenase (LDH) and its release in apoptotic stromal cells. By adding viable and dead cell numbers (total cells), the fraction of dead cells (Dead cells/Total cells) was estimated to be $0.12 \pm 0.04$ in $2 \mathrm{D}$ and $0.16 \pm 0.02$ in 3D cultures before $300 \mathrm{~h}$ (Fig. 2b). After $300 \mathrm{~h}$, the dead cells in 3D cultures increased to $0.4 \pm 0.06$ and remained around $0.12 \pm 0.04$ in $2 \mathrm{D}$ (Fig. 2b). Consequently, cell death in 3D could only account for low cell numbers after $300 \mathrm{~h}$. At this time point, concentrations of ammonia (Fig. 2c) and lactate (Fig. 2d) in the bulk medium rose to harmful levels [26] in both 2D and 3D, thus showing that the waste accumulation in the bulk medium becomes equally toxic for MSCs in these different culture systems.

\subsection{Can mutrient gradients determine cells' spatiotemporal organization?}

We used glucose as a model molecule for molecular gradients

concentrations consistently increase in both culture systems (c). Lactate accumulation is analyzed (d) and kinetically quantified according to $q_{l}$ values (e). Measurements in time represent the mean and standard deviation ( $n=3$ donors, $n^{\prime}=6$ samples/donor). The residual and differences between kinetic model and measurement values yield the standard error of estimates (SEE). $q_{l}$ was estimated with nlinfit and nlparci functions of Matlab with statistical significance set at $\mathrm{p} \leq 0.05$. 

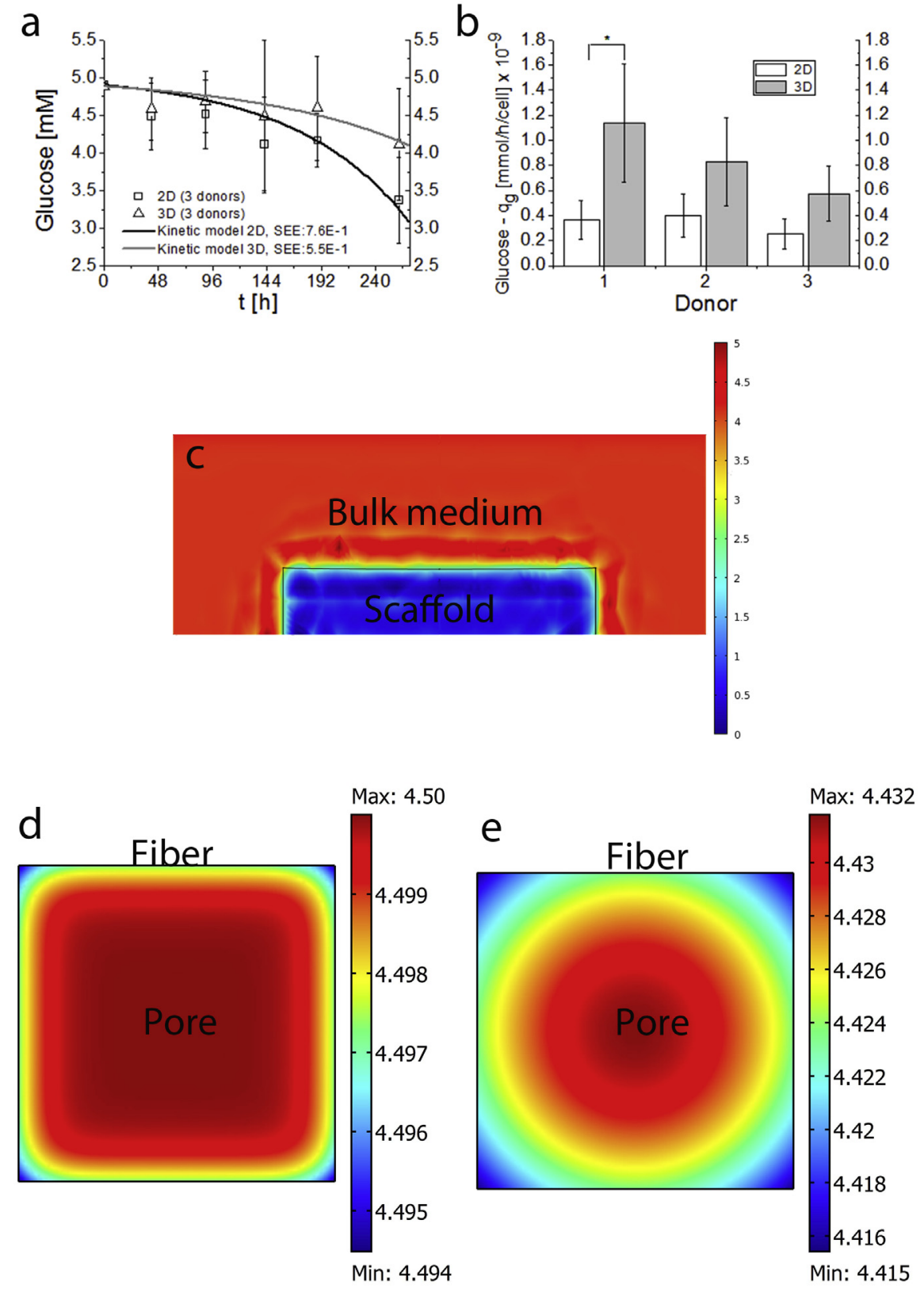

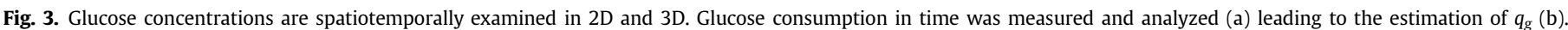

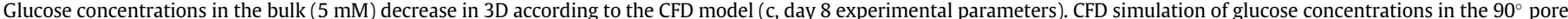

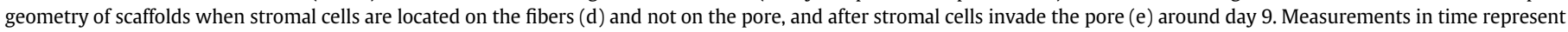

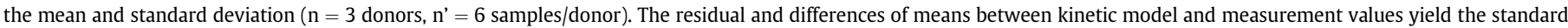
error of estimates (SEE). $q_{g}$ was estimated with nlinfit and nlparci functions of Matlab with statistical significance set at $\mathrm{p} \leq 0.05$.

and assessed whether the bulk concentration of glucose was depleted in time. Glucose is a small molecule $(1 \mathrm{~nm})$ compared to growth factors $(>100 \mathrm{~nm}$ ). However, glucose tractability makes it an ideal molecule for studies in scaffolds because its physical dynamics and biological roles have been extensively investigated. Glucose decreased faster in 2D than in 3D (Fig. 3a), but was never depleted in any culture. Since glucose kinetics is cell-numberdependent, glucose consumption rates (mM Glucose/cell/h) (Fig. 3b) were quantified [24]. This led to estimating higher glucose consumption rates in $3 \mathrm{D}$, which were only significantly higher for donor 1 . To assess the spatiotemporal concentration of glucose, consumption rates and cell numbers were used to predict glucose concentrations inside the 3D geometry (Fig. 3c) with a computational fluid dynamics (CFD) model (Eq. (1)). As expected, the CFD model and experimental measurements highlighted that glucose was not depleted in the bulk of 3D cultures. Similarly, the CFD model showed that regions of high glucose concentration (Fig. 3c) corresponded with the scaffold's periphery where dividing MSCs were detected (Fig. 1d). Also, glucose concentrations in the rectangular pore geometry of the scaffold decreased from the center of the pore (Fig. 3d) (higher glucose concentrations) towards the fibers (lower glucose concentrations); the gradient shape varied depending on whether cells were positioned on top of fibers (Fig. 3d) or located circularly on the pore itself (Fig. 3e).

It was possible to interfere with MSCs proliferation into the pores by performing the $3 \mathrm{D}$ cell culture in a perfusion bioreactor 
Table 1

List of differentially-regulated probes of stromal cells from 3 different donors grown on a 2D compared to a 3D system. Values represent a $\log 2$ fold change $[\log 2(2 \mathrm{D} / 3 \mathrm{D})]$ and statistically significant genes are indicated in bold red (FDR $<5 \%$ ).

\begin{tabular}{|c|c|c|c|c|c|}
\hline \multicolumn{6}{|c|}{ Higher Expressed in 3D } \\
\hline ProbeID & GeneName & Description & Donor1 & Donor2 & Donor3 \\
\hline ILMN_2234697 & BEX1 & brain expressed, X-linked 1 (BEX1). & -2.22 & -0.84 & -0.43 \\
\hline ILMN_1707727 & ANGPTL4 & angiopoietin-like 4 (ANGPTL4), transcript variant 1 . & -2.16 & -0.20 & -0.97 \\
\hline ILMN_2370624 & COL13A1 & collagen, type XIII, alpha 1 (COL13A1), transcript variant 9. & -2.06 & -0.31 & -0.29 \\
\hline ILMN_2311052 & COL13A1 & collagen, type XIII, alpha 1 (COL13A1), transcript variant 19. & -0.99 & -0.37 & -0.36 \\
\hline ILMN_2352097 & GPR56 & G protein-coupled receptor 56 (GPR56), transcript variant 2. & -1.75 & -0.36 & -0.71 \\
\hline ILMN_2384122 & GPR56 & G protein-coupled receptor 56 (GPR56), transcript variant 3. & -1.90 & -0.40 & -0.67 \\
\hline ILMN_1699421 & ANXA10 & annexin A10 (ANXA10). & -1.83 & -0.53 & -0.12 \\
\hline ILMN_1651354 & SPP1 & secreted phosphoprotein 1 (SPP1), transcript variant 2. & -1.80 & 1.39 & 0.28 \\
\hline ILMN_2374449 & SPP1 & secreted phosphoprotein 1 (SPP1), transcript variant 1. & -0.95 & 1.40 & 0.50 \\
\hline ILMN_1810376 & C11ORF87 & chromosome 11 open reading frame 87 (C11orf87). & -1.69 & -0.64 & -0.26 \\
\hline & & ADAM metallopeptidase with thrombospondin type 1 motif, 1 & & & \\
\hline ILMN_1673566 & ADAMTS1 & (ADAMTS1). & -1.60 & -0.81 & -1.39 \\
\hline ILMN_1691884 & STC2 & stanniocalcin 2 (STC2). & -1.39 & -0.80 & -1.05 \\
\hline ILMN_1748840 & CALB2 & calbindin 2 (CALB2), transcript variant CALB2c. & -1.16 & 0.50 & 0.11 \\
\hline ILMN_1758164 & STC1 & stanniocalcin 1 (STC1). & -1.07 & -1.16 & -1.72 \\
\hline \multicolumn{6}{|c|}{ Higher Expressed in 2D } \\
\hline ProbeID & GeneName & Description & Donor1 & Donor2 & Donor3 \\
\hline ILMN_1774077 & GBP2 & guanylate binding protein 2 , interferon-inducible (GBP2). & 1.00 & 0.07 & 0.64 \\
\hline ILMN_1761425 & OLFML2A & olfactomedin-like 2A (OLFML2A). & 1.00 & 0.78 & 0.49 \\
\hline ILMN_3245678 & RNU1A3 & RNA, U1A3 small nuclear (RNU1A3), small nuclear RNA. & 1.02 & 0.42 & 0.56 \\
\hline ILMN_1754969 & LMCD1 & LIM and cysteine-rich domains 1 (LMCD1). & 1.05 & 0.70 & 0.59 \\
\hline ILMN_2347592 & NMB & neuromedin $B(\mathrm{NMB})$, transcript variant 1 . & 1.08 & 0.88 & 0.43 \\
\hline ILMN_2325763 & VCAM1 & vascular cell adhesion molecule 1 (VCAM1), transcript variant 2 . & 1.25 & 0.04 & 0.27 \\
\hline ILMN_2307903 & VCAM1 & vascular cell adhesion molecule 1 (VCAM1), transcript variant 1 . & 0.75 & 0.52 & 0.89 \\
\hline ILMN_1766955 & VCAM1 & vascular cell adhesion molecule 1 (VCAM1), transcript variant 1 . & 0.88 & 0.37 & 0.02 \\
\hline ILMN_1655915 & MMP11 & matrix metallopeptidase 11 (stromelysin 3) (MMP11). & 1.28 & 1.13 & 1.11 \\
\hline & & v-maf musculoaponeurotic fibrosarcoma oncogene homolog B & & & \\
\hline ILMN_1764709 & MAFB & (avian) (MAFB). & 1.36 & 0.42 & 1.05 \\
\hline ILMN_1664464 & PTGDS & prostaglandin D2 synthase $21 \mathrm{kDa}$ (brain) (PTGDS). & 1.76 & 2.25 & 1.10 \\
\hline ILMN_2390853 & CTSH & cathepsin $\mathrm{H}(\mathrm{CTSH})$, transcript variant 1 . & 2.05 & 0.44 & 0.77 \\
\hline ILMN_1740938 & $\mathrm{APOE}$ & apolipoprotein E (APOE). & 2.17 & 1.35 & 0.27 \\
\hline ILMN_1810172 & SFRP4 & secreted frizzled-related protein 4 (SFRP4). & 3.31 & 0.59 & 0.26 \\
\hline ILMN_1696537 & DDIT4L & DNA-damage-inducible transcript 4-like (DDIT4L). & 2.75 & -0.13 & 0.99 \\
\hline ILMN_1688780 & S100A4 & S100 calcium binding protein A4 (S100A4), transcript variant 2 . & -0.99 & 0.47 & 1.06 \\
\hline ILMN_1684306 & S100A4 & S100 calcium binding protein A4 (S100A4), transcript variant 2 . & -0.78 & 0.62 & 0.84 \\
\hline ILMN_1726928 & TCEA3 & transcription elongation factor A (SII), 3 (TCEA3). & 0.29 & 0.66 & 0.72 \\
\hline ILMN_1718766 & MT1F & metallothionein $1 \mathrm{~F}$ (MT1F). & 0.14 & 0.76 & 1.23 \\
\hline
\end{tabular}

(see Fig. 2a, b in Ref. [25]), where convection aggregated MSCs on fibers both across the width (see Fig. 2a in Ref. [25]) and the height (see Fig. 2b in Ref. [25]) of the scaffold. Stromal cells aggregated into colonies on fibers (see Fig. 2c in Ref. [25]). Dissolved oxygen (DO) measurements (see Fig. 2d in Ref. [25]) reflected a 4-day lag and 3day proliferation phases whose duration can be adjusted following the relation between medium flow and the residence time of cells in the bioreactor. In this manner, convection was the only factor that prevented cell proliferation towards the center of the pore, yet it supported cell proliferation on the scaffold's fibers.

\subsection{Which extracellular matrix components are expressed in $3 D$ ?}

We measured glycosaminoglycans (GAG) and total collagen (see Fig. 3a and c in Ref. [25]) in time, since these proteins are commonly abundant in mammalian tissues. We found that GAG could be 
detected in all stromal cell donors. As estimated with the kinetic model [24], MSCs produced GAG at comparable rates in 2D and 3D (see Fig. 3b in Ref. [25]). Surprisingly, hydroxyproline or total collagen (see Fig. 3c in Ref. [25]) indicated that only one donor in 3D produced collagen, although collagen could be detected in all 2D cultures. Hence, 3D culture leads to a different extracellular matrix (ECM) composition than 2D culture.

\subsection{What molecular mechanisms regulate stromal cells behavior in} $3 D ?$

In order to better understand the transcriptional changes that led to the observed spatiotemporal organization and kinetic differences, we performed a whole-genome gene expression analysis on mesenchymal stromal cells cultured for 7 days on 2D vs. 3D cultures and generated a full list of genes differentially regulated in at least two out of the three donors tested (Table 1). The analysis of the list showed that the number of differentially expressed genes in all the donors was rather limited indicating that changes in gene expression were not affected by the culture conditions (2D vs 3D) or that the specific variations in gene expression cannot be detected using whole-genome analysis. Nevertheless, the analysis showed that stanniocalcin-1 (STC1) was the only gene whose expression was 2-fold higher in all three donors in 3D cultures for all the donors tested. In addition, matrix metalloproteinase-11 (MMP11) and prostaglandin D2 synthase (PTGDS) were genes whose expression was 2-fold higher in 2D cultures for all donors tested.

\subsection{How does $3 D$ stromal cell culture affect tissue in vivo?}

We implanted 3D scaffolds in nude mice and found that (see Fig. 4 in Ref. [25]) they did not show any qualitative difference with or without cells. Specifically, implanting scaffolds seeded with MSCs organized in the pores (As in Fig. 1) did not lead to any noteworthy difference with implanting scaffolds without cells according to intracellular (Nuclei and cytoplasma, see Fig. 4a in Ref. [25]) and extracellular (Collagen or keratin, see Fig. 4b in Ref. [25]) markers. Since any MSCs regenerative effect, when implanted, would be considerably diluted in host tissue, we decided to increase the numbers of stromal cells in scaffolds $\left(3 \times 10^{3}\right.$ cells $\left./ \mathrm{ml}\right)$ by using wells [22], where 3 to $14 \times 10^{6}$ cells $/ \mathrm{ml}$ can be seeded before implantation in nude mice. Tissue markers specific for collagen (see Fig. 5 in Ref. [25]) revealed that wells without implanted cells (see Fig. 5A, B in Ref. [25]) and wells carrying 3 to $6 \times 10^{6}$ cells/ml (see Fig. 5C, D in Ref. [25]) contained connective tissue similar to what was observed in PEOT/PBT scaffolds (see Fig. 4 in Ref. [25]). Wells containing $14 \times 10^{6}$ cells $/ \mathrm{ml}$ displayed aligned collagen fibers and blood vessels (see Fig. 5G, H in Ref. [25]). We confirmed the presence of blood vessels via CD31 staining (Fig. 4). Despite high autofluorescence of the PEOT/PBT copolymer, it was possible to elucidate through image analysis that there were a significantly higher $\left(\mathrm{p}<8 \times 10^{-4}\right)$ number of blood vessels in the condition seeded with $14 \times 10^{6}$ cells $/ \mathrm{ml}$ at week 2 (Fig. 4f), but not significant at week 4 despite preserving the same trend (Fig. 4g). On the other hand, total vessel area and average vessel size were not significantly different (see Fig. 6 in Ref. [25]) in any of the conditions tested. To assess the molecular effect of implanting stromal cells at high concentrations, we verified the expression of STC1 (Fig. 5) in slices of tissue. Upon quantification of $\mathrm{STC} 1^{+}$pixels, there were significantly $(\mathrm{p}<0.03)$ higher amounts of STC1 in wells containing $14 \times 10^{6}$ cells $/ \mathrm{ml}$ at week 2 (Fig. 5F), but not at week 4 (Fig. 5G). Mean intensity values found on the histograms showed increasing intensity values as cell concentrations were increased (Fig. 5 A-D). Without the STC1 antibody, mean intensity values of Cy5 (secondary antibody) were several magnitudes lower $\left(<1 \times 10^{-3}\right)$ than sections incubated with the STC1 antibody (see Fig. 7 in Ref. [25]). These confirmed the presence of STC1 protein in wells containing cells. With regards to the amount of STC1 in wells, the STC1+ pixels were found to account for up to $9.54 \times 10^{-4} \%$ of all pixels in an image according to the estimated pixels ${ }^{2}$ after STC1 quantification (Fig. 5F) over the image size (that is: 250 pixels $^{2} / 2.62 \times 10^{5}$ pixels $^{2}$ ). Notably, our STC1 quantification is consistent with the orders of magnitude reported for percentage of STC1 protein over total protein $\left(2 \times 10^{-4} \%\right)$ in pellets of 25,000 MSCs [27], which was also the maximum cell number seeded here per well Altogether, the data showed a consistent expression of STC1 in 3D environments.

\section{Discussion}

The proliferative state of MSCs is dependent on the environment, which can be defined spatially by culturing them in 2D and 3D or temporally by nutrient or space limitation. We chose PEOTPBT because its biocompatibility has been extensively studied and the processing of PEOT/PBT biomaterials into a 2D system as a film and into a 3D system as a scaffold enabled us to control three physical parameters: cell seeding density, pore geometry and shear stress. The cell seeding density is important because it has an effect on the number of cell divisions [28] and differentiation potential [4] of MSCs in culture and their ability to regenerate tissue, such as bone [29]. Therefore, the seeding density was controlled through the surface area in both 2D and 3D. Kinetically, MSCs displayed more proliferative capacity in $2 \mathrm{D}$ than in $3 \mathrm{D}$, despite a comparable surface area of attachment. This indicated that a higher cell concentration (cells $/ \mathrm{ml}$ ) in 3D than in 2D could be an important factor in modulating the specific growth rate of MSCs. How the modulation occurs is of paramount importance, especially considering the fact that the surface area is not limiting proliferation in 3D because, as it was shown here, MSCs can make use of the porosity to expand. The 3D environment exhibits localized regions of proliferation, specifically in the exterior vs. the center of the scaffold. The localization of cell proliferation means that a stromal cell adapts its specific growth rate spatiotemporally in the scaffold. The result of that adaptation is that the specific growth rate for the entire population of cells is lower in 3D than in 2D. Further evidence supporting an adaptive behavior by MSCs under nutrient limitation in 3D is provided by cell death, which is not significantly higher until day 12 of culture approximately. This suggests that the proliferative capacity of MSCs varies according to their spatial location on the scaffold until the accumulation of waste products [26], such as lactate and ammonia, induce significant cell death. Progressively, as MSCs in 3D multiply and the attachment area becomes smaller, cells bridge the interconnected fibers with a tissue deposition rate [30] that is modulated by the pore architecture [31]. This affects the microenvironment in 3D because cell distribution changes as MSCs occupy pores in circular patterns that span the XYZ axis of the scaffold independently of pore-size and architecture. The importance of bioreactor cultures is that convection, which causes shear stress [32], was the only factor that prevented MSCs from occupying the center of the pore while supporting cell proliferation. This has two implications: a) molecular stimulation of pathways involved in shear stress [33] may control the migration of stromal cells into empty spaces (e.g. pores in scaffolds) without shear stress; b) if migration is not possible because of shear stress, the MSCs proliferation strategy is to form colonies throughout the 3D environment.

It remained, however, unclear what could guide tissue deposition in the inner pore space, when the attachment surface provided by the scaffold is depleted. Therefore, we considered the possibility that nutrient-availability (e.g. glucose) could stimulate stromal cell 


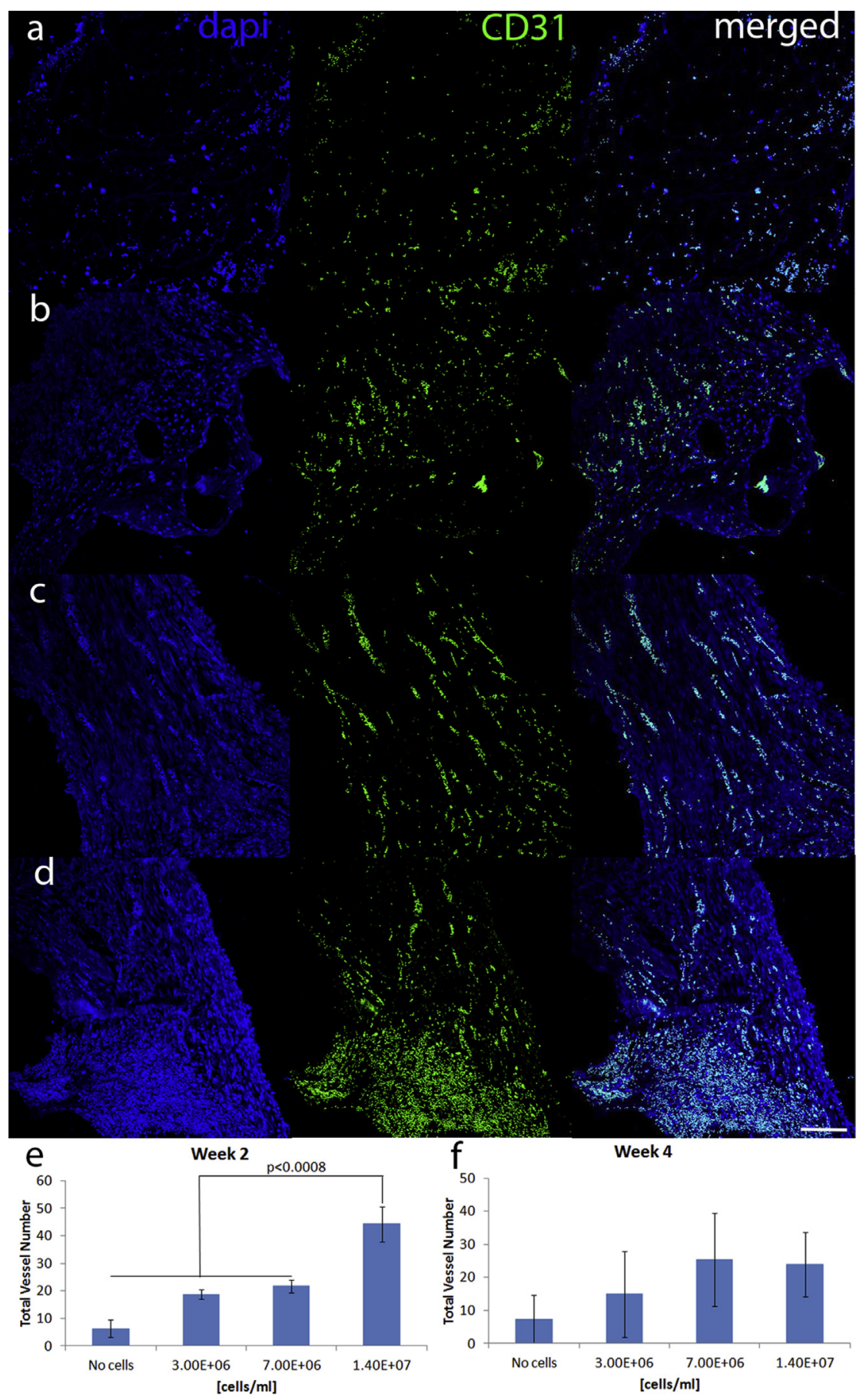

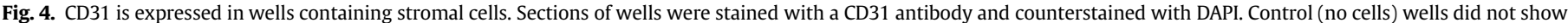

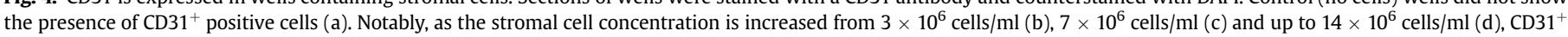

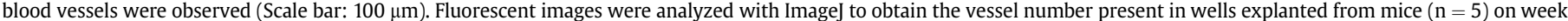
2 (e, $\mathrm{n} \geq 15$ images/condition) and from mice $(\mathrm{n}=5$ ) on week 4 (f, $\mathrm{n} \geq 15$ images/condition).

proliferation beyond attachment to surfaces, since nutrients, growth factors, and mitogens determine whether cells proliferate, undergo quiescence, or apoptosis [34]. Thereby, glucose was monitored in 2D and 3D as a model molecule and major energy source with well-known reaction rates by stromal cells [12, 35, 36]. In our study, glucose displayed comparable values for kinetic parameters $\left(q_{g}\right.$ and $\left.q_{l}\right)$ in 2D and in 3D. In this manner, kinetic parameters were used to reconstruct nutrient availability in 3D through computational fluid dynamics. The spatiotemporal evolution of nutrient gradients $[14,37]$ have been shown to influence stromal cell proliferation [12] and chondrocyte kinetics [13, 21]. Thus, the CFD model illustrated that glucose depletion occurred from the bottom of the scaffold expanding upwards in the XYZ pore geometry, which spatiotemporally prevented MSCs from entering the cell cycle [34] gradually from the bottom to the top of the scaffold. According to the mathematical correlation between cell number and nutrient concentration, the CFD model supported a correlation between nutrient availability and the direction of cell 


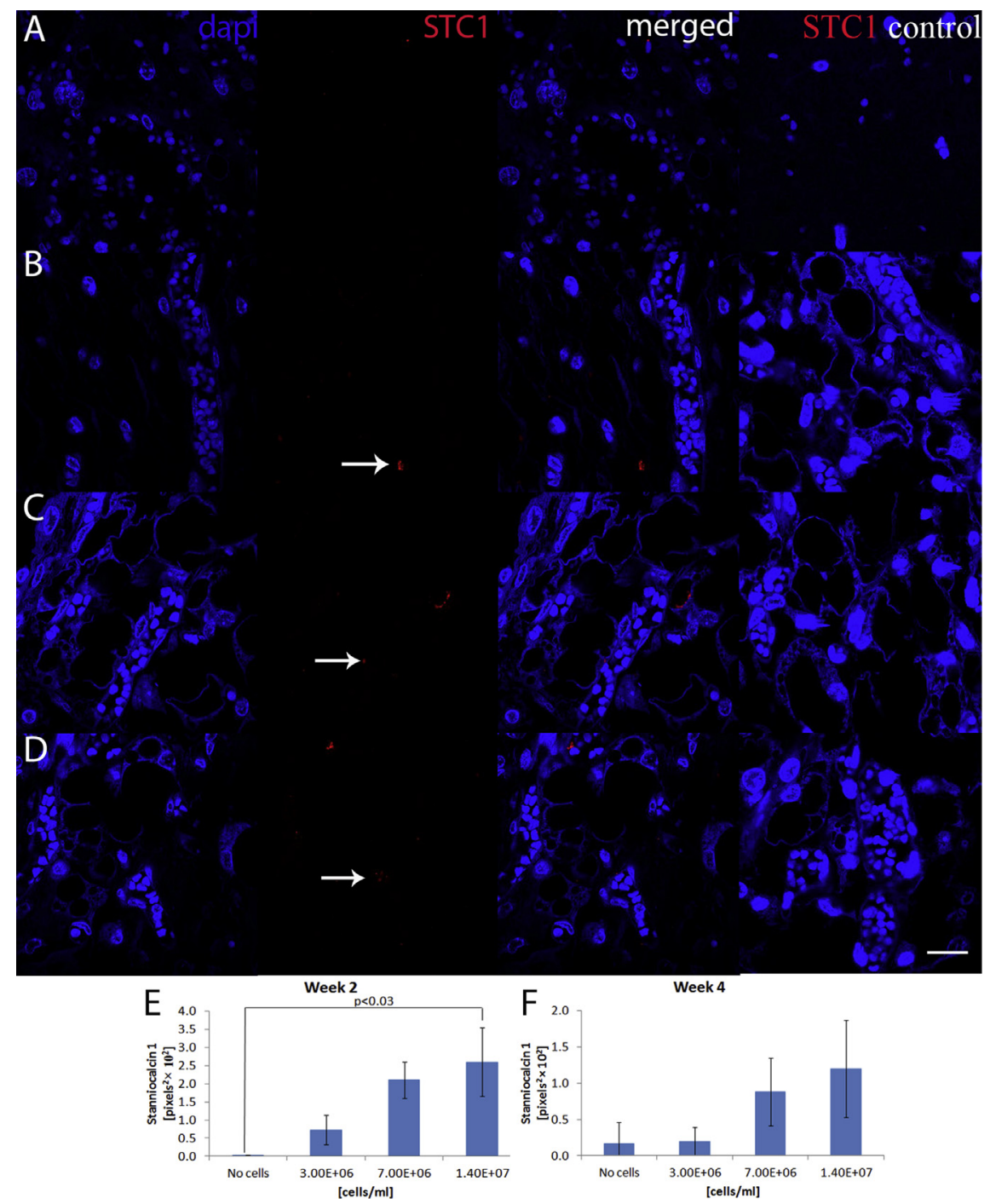

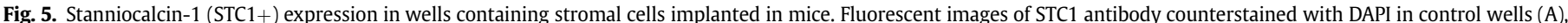

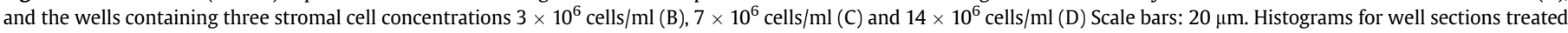

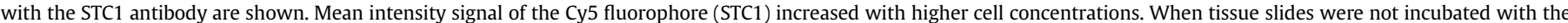

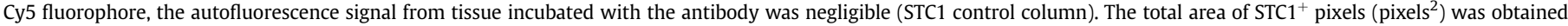
with Image from explanted wells on week 2 ( $E, n \geq 15$ images/condition) and week 4 ( $\mathrm{n}, \mathrm{n} \geq 15$ images/condition).

proliferation, which would be towards regions of high concentration of nutrients. In this time-dependent process, the region of high nutrient availability in the center of the 3D pore became smaller as cells surrounded it from all sides in a circular 3D pattern.

Due to their natural importance in the ECM [38, 39], components such as collagen and proteoglycans were investigated. The production of extracellular matrix (ECM) is time- and cell concentration-dependent. First, our findings suggested that MSCs in scaffolds did not produce collagen because of the low cell concentrations, which make the formation of strong connective tissue unnecessary. On the other hand, stromal cells in 2D needed the connective tissue to maintain increasing cell concentrations supported by better nutrient availability. Just as cell concentrations are driven by nutrient availability, it can be speculated that higher collagen production was also facilitated by the expected higher availability of collagen components, such as Proline and Glycine in 2D [24]. As a result of cell concentrations and nutrient availability, MSCs in scaffolds proliferated into the pores supported by an ECM composed mostly of GAGs. Despite the low amounts of measured
GAGs compared to pellet cultures of MSCs [40], histological analysis for GAGs showed that stromal cells adhesion into the center of the pore was morphologically supported by a loosely associated ECM with nodules of stromal cells organized into circular patterns. This organization occurred in all axis of the interconnected pore network with an ECM that had similar structural characteristics to those observed during mesenchymal morphogenesis [18].

Whole-genome analysis showed that MSCs growing in 2D or 3D have similar expression profiles and eventually only localized differences within given areas of the 3D scaffold lead to marked changes in gene expression. In that respect, it is interesting to note that cells grown in 3D, despite a limited number of genes differentially regulated, display higher expression of genes known to be involved in hypoxia signaling such as stanniocalcin 1 and 2 . The hypoxic environment can be seen through the cell concentration in 3D scaffolds, whose initial cell concentration is $6.7 \times 10^{3}$ cells $/ \mathrm{ml}$ of medium in both 2D and 3D when the medium's volume $(4 \mathrm{ml})$ is considered. However, the cell concentration is actually higher in 3D $\left(3.8 \times 10^{5}\right.$ cells $/ \mathrm{ml}$ of scaffold $)$ when the scaffold's volume 
$\left(7 \times 10^{-2} \mathrm{ml}\right)$ is regarded. Because of the proximity of cells on all three axes, the 3D scaffold would stimulate the rapid onset of a hypoxic environment despite similar culture parameters such as attachment material and its surface areas. When STC1 injection in rats was reported to rescue retinal function [41], we wondered if MSCs concentrated in wells would further stimulate the expression of STC1 and/or induce other tissue regeneration effects. As it turned out, both are possible. However, it could not be determined whether STC1 protein induces vessel formation in the wells or its presence is purely coincidental with blood vessels. Though, confirmation for this could be obtained by evaluating blood vessel formation after subcutaneous injection of STC1 in mice provided that technical challenges, such as STC1 dilution in the blood stream, can be contained within a tissue volume similar to the one created with the implantable wells.

Based on kinetics data and whole genome gene expression analysis, it seems that MSCs in 2D undergo a consistent cycle of matrix production and remodeling. This is supported by MMP11 and PTGDS, whose expression may be linked to a functional role in collagen homeostasis [42] and collagen-induced signaling [43], respectively. Conversely, MSCs in scaffolds experience a hypoxiarelated process of metabolic adaptation. STC1 encodes a secreted, homodimeric glycoprotein that has auto- and paracrine functions in a variety of tissues. Notably, the STC1 gene contains a hypoxiaresponsive element (HRE) motif and therefore is a hypoxia inducible factor (HIF) target gene [40]. It has been shown that STC1 has anti-apoptotic effects in MSCs [44], which would explain stable and comparable cell death in 3D vs. 2D despite steep gradients that cause nutrient limitation in 3D. Moreover, our results in vitro and in vivo suggest that the stromal cell-STC1-concentration correlation might be involved in the promotion of vessel formation in 3D through a mechanism that might be analogous to that of tumor growth via a vascular endothelial growth factor (VEGF) dependent mechanism [45]. However, further studies are needed to confirm STC1 involvement in vessel formation via the implantation of MSCs where STC1 gene expression is knocked out. We found that MSCs organization in scaffolds did not yield any particular effect in vivo probably due to low cell concentrations in the implanted scaffold volume $\left(5 \times 10^{3}\right.$ cells $\left./ \mathrm{ml}\right)$. We then increased the cell concentrations by decreasing the in vivo stromal cells-culture-volume. This showed that it takes over $14 \times 10^{6}$ cells $/ \mathrm{ml}$ to detect any hypoxiarelated effect such as vessel formation, which means that increasing MSCs concentrations by decreasing culture volumes is an effective strategy for stimulating therapeutic effects in vivo, such as vessel formation. However, further research in this direction is required to assess the presence of VEGF-dependent vessel formation, the fluctuations of STC1 in vivo (week 2 vs. week 4) and the main roles played by host vs. implanted cells in angiogenesis in 3D. Concerning the latter, it could not be determined whether stromal cells induced vessel formation themselves or through host tissue since all of the antibodies tested showed species cross-reactivity. In any case, the data indicate that increasing cell concentrations induce hypoxia and STC1 expression. The expression of STC1 in vitro and vivo may be connected to the delay in growth -or the difference in specific growth rates-observed in $3 \mathrm{D}$ vs. $2 \mathrm{D}$ which suggests that MSCs in 3D manage their resources carefully to the point of becoming almost quiescent. The specific growth rates in $3 \mathrm{D}$ indicate the proliferation of a subpopulation of MSCs at the pores of scaffolds, which compete for nutrients and orchestrate the spatiotemporal organization of MSCs in the pores. Similar to cells in the pores of scaffolds in vitro, MSCs contained in wells in vivo bear stringent competition for nutrients as well, which stimulates vessel formation only with high numbers of cells $\left(>6 \times 10^{6}\right.$ cells $\left./ \mathrm{ml}\right)$. In summary, our results indicate that for MSCs, the dimensions of the 3D environment determine their proliferation rate $(\mu)$, spatial organization, molecular pathway commitment and potential regeneration of tissue.

\section{Conclusions}

We show that by harnessing cell numbers into small volumes, molecular gradients are minimized whereas the angiogenesis potential of stromal cells is maximized. In practice, this means that effective stromal cell treatments require cell concentrations $\left(>1 \times 10^{7}\right.$ cells $\left./ \mathrm{ml}\right)$, which had not been technically possible to achieve in vivo. Here, we describe why cell concentrations are paramount as physiological parameters, which is most likely also crucial in other cell therapy applications.

\section{Disclosure}

\section{G.A. Higuera is a shareholder of Screvo B.V.}

\section{Acknowledgments}

The authors acknowledge the financial support from the Dutch SenterNovem research grant No. 15044112 and pre-seed grant No. 93611002 of the Netherlands Genomics Initiative.

\section{References}

[1] R. Strauss, P. Hamerlik, A. Lieber, J. Bartek, Regulation of stem cell plasticity: mechanisms and relevance to tissue biology and cancer, Mol. Ther. J. Am. Soc. Gene Ther. 20 (5) (2012) 887-897. Epub 2012/02/09.

[2] D.O. Freytes, L.Q. Wan, G. Vunjak-Novakovic, Geometry and force control of cell function, J. Cell. Biochem. 108 (5) (2009) 1047-1058.

[3] U.A. Gurkan, O. Akkus, The mechanical environment of bone marrow: a review, Ann. Biomed. Eng. 36 (12) (2008) 1978-1991. Epub 2008/10/16.

[4] R. McBeath, D.M. Pirone, C.M. Nelson, K. Bhadriraju, C.S. Chen, Cell shape, cytoskeletal tension, and RhoA regulate stem cell lineage commitment, Dev. Cell. 6 (4) (2004) 483-495.

[5] S. Ruiz, C. Chen, Emergence of patterned stem cell differentiation within multicellular structures, Stem Cells 26 (11) (2008) 2921-2927.

[6] P. Angele, D. Schumann, M. Angele, B. Kinner, C. Englert, R. Hente, et al., Cyclic, mechanical compression enhances chondrogenesis of mesenchymal progenitor cells in tissue engineering scaffolds, Biorheology 41 (3-4) (2004) $335-346$.

[7] V. Terraciano, N. Hwang, L. Moroni, H.B. Park, Z. Zhang, J. Mizrahi, et al., Differential response of adult and embryonic mesenchymal progenitor cells to mechanical compression in hydrogels, Stem Cells 25 (11) (2007) 2730-2738. Epub 2007/08/19.

[8] R.L. Carrier, M. Rupnick, R. Langer, F.J. Schoen, L.E. Freed, G. Vunjak-Novakovic, Effects of oxygen on engineered cardiac tissue, Biotechnol. Bioeng. 78 (6) (2002) 617-625.

[9] J. Malda, T.J. Klein, S. Upton, The roles of hypoxia in the in vitro engineering of tissues, Tissue Eng. 9 (2007) 2153-2162.

[10] M. Radisic, J. Malda, E. Epping, W. Geng, R. Langer, G. Vunjak-Novakovic, Oxygen gradients correlate with cell density and cell viability in engineered cardiac tissue, Biotechnol. Bioeng. 2 (2006) 332-343.

[11] X. Wang, E. Wenk, X. Zhang, L. Meinel, G. Vunjak-Novakovic, D. Kaplan, Growth factor gradients via microsphere delivery in biopolymer scaffolds for osteochondral tissue engineering, J. Control Release 134 (2) (2009) 81-90.

[12] F. Zhao, P. Pathi, W. Grayson, Q. Xing, B.R. Locke, T. Ma, Effects of oxygen transport on 3-D human mesenchymal stem cell metabolic activity in perfusion and static cultures: experiments and mathematical model, Biotechnol. Prog. 21 (4) (2005) 1269-1280.

[13] T.W. Spitters, C.M. Mota, S.C. Uzoechi, B. Slowinska, D. Martens, L. Moroni, et al., Glucose gradients influence zonal matrix deposition in 3D cartilage constructs, Tissue Eng. Part A 20 (23-24) (2014 Dec) 3270-3278.

[14] H.C. Berg, Random Walks in Biology, Expanded ed., Princeton University Press, Princeton, N.J, 1993, 152 p.

[15] W.L. Grayson, F. Zhao, R. Izadpanah, B. Bunnell, T. Ma, Effects of hypoxia on human mesenchymal stem cell expansion and plasticity in 3D constructs, J. Cell. Physiol. 207 (2) (2006) 331-339.

[16] B. Markway, G. Tan, G. Brooke, J. Hudson, J. Cooper-White, M. Doran, Enhanced chondrogenic differentiation of human bone marrow-derived mesenchymal stem cells in low oxygen environment micropellet cultures, Cell Transpl. 19 (1) (2010) 29-42 [Epub ahead of print].

[17] A. Caplan, J. Dennis, Mesenchymal stem cells as trophic meadiators, J. Cell. Biochem. 98 (2006) 1076.

[18] G. Forgács, S. Newman, Biological Physics of the Developing Embryo, Cambridge University Press, Cambridge, 2005 vi, 337 p. 
[19] J. Green, Morphogen gradients, positional information, and xenopus: interplay of theory and experiment, Dev. Dyn. 225 (2002) 392-408.

[20] A. Touring, The chemical basis of morphogenesis, Philos. Trans. R. Soc. Lond. Ser. B Biol. Sci. 237 (641) (1952) 37-72.

[21] S. Zhou, Z. Cui, J.P. Urban, Nutrient gradients in engineered cartilage: metabolic kinetics measurement and mass transfer modeling, Biotechnol. Bioeng. 101 (2) (2008) 408-421. Epub 2008/08/30.

[22] G.A. Higuera, J.A. Hendriks, J. van Dalum, L. Wu, R. Schotel, L. Moreira-Teixeira, et al., In vivo screening of extracellular matrix components produced under multiple experimental conditions implanted in one animal, Integr. Biol. (Camb.) 5 (6) (2013) 889-898. Epub 2013/05/09.

[23] J.M. Wettenhall, G.K. Smyth, limmaGUI: a graphical user interface for linear modeling of microarray data, Bioinformatics 20 (18) (2004) 3705-3706.

[24] G.A. Higuera, D. Schop, T.W. Spitters, R. van Dijkhuizen-Radersma, M. Bracke, J.D. de Bruijn, et al., Patterns of amino acid metabolism by proliferating human mesenchymal stem cells, Tissue Eng. Part A 18 (5-6) (2012) 654-664. Epub 2011/09/29.

[25] GA Higuera, H Fernandes, TWGM Spitters, J van de Peppel, N Aufferman, R Truckenmueller, et al., Supporting Data of Spatiotemporal Proliferation of Human Stromal Cells Adjusts to Nutrient Availability and Leads to Stanniocalcin-1 Expression In Vitro and In Vivo. Data in Brief. Submitted.

[26] D. Schop, F. Janssen, Rijn Lv, H. Fernandes, Jd Bruijn, Rv Dijkhuizen-Radersma, Growth, metabolism and growth inhibitors of mesenchymal stem cells, Tissue Eng. Part A (2009) 15.

[27] T.J. Bartosh, J.H. Ylostalo, A. Mohammadipoor, N. Bazhanov, K. Coble, K. Claypool, et al., Aggregation of human mesenchymal stromal cells (MSCs) into 3D spheroids enhances their antiinflammatory properties, Proc. Natl. Acad. Sci. U. S. A. 107 (31) (2010) 13724-13729. Epub 2010/07/21.

[28] I. Sekiya, B.L. Larson, J.R. Smith, R. Pochampally, J.-G. Cui, D.J. Prockop, Expansion of human adult stem cells from bone marrow stroma: conditions that maximize the yields of early progenitors and evaluate their quality, Stem Cells 20 (2002) 530-541.

[29] F. Luo, T.Y. Hou, Z.H. Zhang, Z. Xie, X.H. Wu, J.Z. Xu, Effects of initial cell density and hydrodynamic culture on osteogenic activity of tissue-engineered bone grafts, PLoS One 8 (1) (2013) e53697. Epub 2013/01/18.

[30] C.M. Bidan, K.P. Kommareddy, M. Rumpler, P. Kollmannsberger, P. Fratzl, J.W. Dunlop, Geometry as a factor for tissue growth: towards shape optimization of tissue engineering scaffolds, Adv. Healthc. Mater. 2 (1) (2013) 186-194. Epub 2012/11/28.

[31] L. Moroni, J.R. de Wijn, C.A. van Blitterswijk, Three-dimensional fiberdeposited PEOT/PBT copolymer scaffolds for tissue engineering: influence of porosity, molecular network mesh size, and swelling in aqueous media on dynamic mechanical properties, J. Biomed. Mater. Res. Part A 75A (4) (2005) 957-965.

[32] F. Zhao, R. Chella, T. Ma, Effects of shear stress on 3-D human mesenchymal stem cell construct development in a perfusion bioreactor system: experiments and hydrodynamic modeling, Biotechnol. Bioeng. 96 (3) (2007) 584-595. Epub 2006/09/02.

[33] J.R. Glossop, S.H. Cartmell, Effect of fluid flow-induced shear stress on human mesenchymal stem cells: differential gene expression of IL1B and MAP3K8 in MAPK signaling, Gene Express. Patterns 9 (5) (2009) 381-388. Epub 2009/03/ 11.

[34] B. Alberts, A. Johnson, J. Lewis, M. Raff, K. Roberts, P. Walter, Molecular Biology of the Cell, fifth ed., Garland Science, New York, 2008, 1268 p.

[35] G. Higuera, D. Schop, F. Janssen, R. van Dijkhuizen-Radersma, T. van Boxtel, C.A. van Blitterswijk, Quantifying in vitro growth and metabolism kinetics of human mesenchymal stem cells using a mathematical model, Tissue Eng. Part A 15 (9) (2009) 2653-2663.

[36] G. Lemon, S.L. Waters, F.R.A.J. Rose, J.R. King, Mathematical modelling of human mesenchymal stem cell proliferation and differentiation inside artificia porous scaffolds, J. Theor. Biol. 249 (3) (2007) 543-553.

[37] R.B. Bird, W.E. Stewart, E.N. Lightfoot, Transport Phenomena, second rev. ed., J. Wiley, New York; Chichester, 2007 xii, 905 pp.

[38] G. Forgacs, S.A. Newman, B. Hinner, C.W. Maier, E. Sackmann, Assembly of collagen matrices as a phase transition revealed by structural and rheologic studies, Biophys. J. 84 (2) (2003) 1272-1280.

[39] S. Newman, M. Cloitre, C. Allain, G. Forgacs, D. Beysens, Viscosity and elasticity during collagen assembly in vitro: relevance to matrix-driven translocation, Biopolymers 41 (3) (1997) 337-347.

[40] A.Y. Law, L.Y. Ching, K.P. Lai, C.K. Wong, Identification and characterization of the hypoxia-responsive element in human stanniocalcin-1 gene, Mol. Cell. Endocrinol. 314 (1) (2010) 118-127. Epub 2009/07/25.

[41] G.W. Roddy, R.H. Rosa Jr., J.Y. Oh, J.H. Ylostalo, T.J. Bartosh Jr., H. Choi, et al, Stanniocalcin-1 rescued photoreceptor degeneration in two rat models of inherited retinal degeneration, Mol. Ther. J. Am. Soc. Gene Ther. 20 (4) (2012) 788-797. Epub 2012/02/02.

[42] J. Tan, E. Buache, F. Alpy, E. Daguenet, C.L. Tomasetto, G.S. Ren, et al., Stromal matrix metalloproteinase- 11 is involved in the mammary gland postnatal development, Oncogene 33 (31) (2014) 4050-4059. Epub 2013/10/22.

[43] N. Maicas, L. Ibanez, M.J. Alcaraz, A. Ubeda, M.L. Ferrandiz, Prostaglandin D2 regulates joint inflammation and destruction in murine collagen-induced arthritis, Arthritis Rheumatism 64 (1) (2012) 130-140. Epub 2011/09/08.

[44] G.J. Block, S. Ohkouchi, F. Fung, J. Frenkel, C. Gregory, R. Pochampally, et al. Multipotent stromal cells are activated to reduce apoptosis in part by upregulation and secretion of stanniocalcin-1, Stem Cells 27 (3) (2009) 670-681 Epub 2009/03/10.

[45] L.F. He, T.T. Wang, Q.Y. Gao, G.F. Zhao, Y.H. Huang, L.K. Yu, et al., Stanniocalcin1 promotes tumor angiogenesis through up-regulation of VEGF in gastric cancer cells, J. Biomed. Sci. 18 (2011) 39. Epub 2011/06/16. 